\title{
Ecological Status of a Margaritifera margaritifera (Linnaeus, 1758) Population at the Southern Edge of its Distribution (River Paiva, Portugal)
}

\author{
Ronaldo Sousa $\cdot$ Ângela Amorim $\cdot$ Carina Sobral $\cdot$ \\ Elsa Froufe - Simone Varandas • Amílcar Teixeira • \\ Manuel Lopes-Lima
}

Received: 16 December 2012/ Accepted: 20 June 2013

(C) Springer Science+Business Media New York 2013

\begin{abstract}
An important population of the critically endangered pearl mussel Margaritifera margaritifera (Linnaeus, 1758) was surveyed at the edge of its southern distribution (River Paiva, Portugal). Although an earlier study suggested that this population had a very low number of individuals $(<500)$, a narrow distribution, and was mainly comprised by old specimens our data contradict these findings. Our assessment estimated a population with probably more than 5,000 individuals distributed across $80 \mathrm{~km}$ of the river length. From the 32 sites surveyed, 19 contained M. margaritifera with higher abundances verified in the middle and upper parts of the river (a maximum of 78 ind. per $100 \mathrm{~m}$ of river stretch
\end{abstract}

R. Sousa $\cdot \hat{A}$. Amorim

CBMA - Centre of Molecular and Environmental Biology,

Department of Biology, University of Minho,

Campus de Gualtar, 4710-057 Braga, Portugal

R. Sousa $(\varangle) \cdot$ C. Sobral · E. Froufe · M. Lopes-Lima CIMAR-LA/CIIMAR - Centre of Marine and Environmental Research, University of Porto, Rua dos Bragas 289, 4050-123 Porto, Portugal

e-mail: ronaldo.sousa@ ciimar.up.pt

S. Varandas

CITAB-UTAD - Centre for Research and Technology

of Agro-Environment and Biological Sciences, University

of Trás-os-Montes and Alto Douro, Forestry Department,

Apartado 1013, 5001-811 Vila Real, Portugal

A. Teixeira

CIMO-ESA-IPB-Mountain Research Centre, School of Agriculture, Polytechnic Institute of Bragança, Campus de Santa Apolónia, Apartado 1172, 5301-854 Bragança, Portugal

M. Lopes-Lima

ICBAS-Instituto de Ciências Biomédicas de Abel Salazar, Universidade do Porto, Largo Prof. Abel Salazar, 2,

4099-003 Porto, Portugal was recorded). The pearl mussels showed a clear preference for areas near the banks, in shallow water, sandier and gravel sediments, and a high degree of riparian vegetation cover. The population structure was skewed with a very high percentage of large (and old) animals but $3.7 \%$ of the individuals collected were juveniles $(<60 \mathrm{~mm}$ in length); therefore, this population can be considered functional. Environmental characterization indicated that this river is still in excellent or good condition although some areas showed deterioration due to discharge of domestic effluents. The main conservation requirements of $M$. margaritifera in the River Paiva include maintaining the water quality (and if possible stopping the discharge of domestic effluents), increasing riparian vegetation cover, removing several weirs to increase connectivity, and increasing trout density.

Keywords Conservation - Distribution - Freshwater pearl mussel $\cdot$ Margaritifera margaritifera $\cdot$ River Paiva

\section{Introduction}

Freshwater ecosystems are threatened with a myriad of human activities which may ultimately affect biodiversity and ecosystem functions and services (Dudgeon and others 2006; Vörösmarty and others 2010). Main threats such as habitat loss and fragmentation as a result of construction of dams or other obstacles, river bank regularization, pollution, introduction of invasive species, overexploitation of resources, and climate change have been accelerating in the last decades and were responsible for the local or even global extinction of several species (Abell and others 2007; Carpenter and others 2011).

Remarkably, there is a considerable taxonomical bias in relation to groups receiving conservation attention in 
freshwater ecosystems (Ricciardi and Rasmussen 1999). Although mammal and bird species receive a majority of this conservation attention and financial support, these species are not always the most threatened, and overlooked groups such as fish, molluscs, and crustaceans deserve further consideration inside freshwaters (Darwall and others 2011).

Freshwater molluscs have been subjected to high rates of extinction or decline in recent decades (Lydeard and others 2004; Régnier and others 2009) with freshwater mussels (order Unionoida) being especially threatened (Strayer and others 2004). One of the most charismatic species inside this group is the critically endangered Margaritifera margaritifera (Linnaeus, 1758), which in recent years has received particular interest, mainly in Europe (Beasley and Roberts 1996; Cosgrove and others 2000; Hastie and others 2000a; Ostrovsky and Popov 2011; Reid and others in press). This interest is probably related with its fascinating life cycle that includes a suitable fish host (Salmo trutta or Salmo salar) and its requirement for exceptional habitat quality (Bauer 1992; Österling and others 2008, 2010). Historically, this species was widespread, but has suffered massive declines both in distribution and abundance in recent decades. Many populations are facing a high risk of extirpation due to recruitment failure (many populations, although containing adults, completely lack juveniles; Geist 2010; Österling and others 2010). Major threats to this critically endangered species include habitat loss and fragmentation; habitat degradation; decline or disappearance of suitable fish hosts; changes in hydrology, chemistry, or geomorphology of streams; and harvesting by humans (for a review see Geist 2010).

While a great number of studies have been done on M. margaritifera, mainly in Northern and Central Europe, populations in the southern part of its distribution have received much less attention (Outeiro and others 2008). Therefore, data about the status of these southern populations are particularly important to follow the possible impact of climate change, for example (Hastie and others 2003). In Portugal, an extensive survey was done by Reis (2003) which recognized the presence of several populations in good condition in the north of the country (Rivers Mente, Rabaçal, and Tuela). This study was particularly relevant because the rediscovery of these populations refuted the idea of the species extinction in Portugal. In addition to the above mentioned rivers, Reis (2003) also found specimens in the Rivers Neiva, Cávado, and Paiva but in these cases only very few individuals were present and mainly comprised adults with no signs of juvenile recruitment. In the last 2 years, additional Portuguese populations were found in the River Tâmega basin (Rivers Beça and Terva; for a full characterization of these populations see Varandas and others 2013).
Considering that freshwater pearl mussels are considered an ideal target species for conservation (this species is usually described as indicator, flagship, keystone, and umbrella species in oligotrophic systems; Geist 2010) it is mandatory that key ecological characteristics (e.g., distribution, abundance, population structure, and characterization of fundamental abiotic conditions) of viable populations are identified. Given the lack of information for M. margaritifera populations at the edge of its global southern distribution and considering that this data is vital for its future conservation, the aims of this study were to: (i) survey the $M$. margaritifera population along the entire extension of the River Paiva; (ii) analyze distribution and population structure; (iii) characterize the abiotic conditions, i.e., water quality and habitat (including river banks); and (iv) give an overview of the most pressing threats to this population and propose conservation/restoration measures which could be implemented in future.

\section{Materials and Methods}

\section{Study Area}

The River Paiva is a tributary of the left margin of the River Douro with a total length of $108 \mathrm{~km}$ and a catchment of $795 \mathrm{~km}^{2}$ entirely located in Portugal. In the headwaters, the river flows through a plateau dominated by areas of agriculture and forestry. In the middle and lower parts, the valley has very steep slopes and is dominated by extensive areas of forestry consisting of mainly pines and eucalyptus, but also with oak and cork. In general this river has well preserved riparian vegetation (e.g., Alnus glutinosa) and water quality is excellent. Important mammal species such as Canis lupus, Galemys pyrenaicus, and Lutra lutra are present in the area. Given its ecological and conservational importance this area is classified as a Natura 2000 site.

\section{Sampling Strategy and Data Analysis}

Characterization of environmental conditions was carried out in July 2012 at five sites along the entire river gradient (sites S8, S40, S64, S82, and S99; Fig. 1). At each site, the following water column parameters were measured: temperature, dissolved oxygen, $\mathrm{pH}$, conductivity, total suspended solids, nitrites, nitrates, phosphates, calcium, and hardness. The first five environmental factors were measured in situ, close to the bottom, by the use of a multiparametrical sea gage YSI 6820. Nitrites, nitrates, and phosphates were determined by molecular-absorption spectrometry; calcium by flame atomic absorption spectrophotometry; and hardness by complete cation analysis (derived from the calcium and magnesium levels). Samples 
of benthic macroinvertebrate fauna were collected with a 0.5-mm mesh hand-net, using semi-quantitative techniques over a 50-m long reach. Organisms were obtained by kicksampling from six transects ( $1 \mathrm{~m}$ long by $0.25 \mathrm{~m}$ wide) covering different habitats (inorganic: coarse, sandy, and muddy substrates; organic: algae, aquatic macrophytes, and organic matter; sedimentation and erosion zones) starting at a riffle. Collections were combined and organisms were sorted in the laboratory. Invertebrates were then preserved in $70 \%$ ethanol and identified to the family level. Data obtained were used to calculate the Water Ecological Status (WES) based on a benthic index of biotic integrity (IPtIN-North Invertebrate Portuguese Index; INAG 2009). Physical habitat characterization was done using the River Habitat Survey (RHS) methodology (Raven and others 1998). A principal components analysis (PCA) in the PRIMER 6 package was used to detect differences between sites and was based on the abiotic, WES, and RHS results.

Assessment of the $M$. margaritifera population in the River Paiva was carried out from March to July 2012 over the total length of the river; comprising 32 different sites (see Fig. 1 for site locations). For each site a river stretch of
$100 \mathrm{~m}$ was visually surveyed using glass bottomed viewers and snorkeling. These surveys were always performed with a minimum of four people spending a minimum of $3 \mathrm{~h}$ in each site. For all mussel specimens, geographic coordinates and five instream attributes (overhead cover found immediately around the mussel location, predominant type of riverbed substrate, current velocity, water depth, and distance from the nearest river bank) were recorded to evaluate the mussel habitat preference. The first three attributes were recorded using qualitative scales: four categories for cover ( 0 absent; 1 roots or vegetation; 2 cobbles or boulders; and 3 bedrock); three categories for the substrate (1 roots; 2 sand and gravel; and 3 cobles, boulders, or bedrock); and six categories for current velocity (qualitative data varying from 0 to 5 where 0 represent a null velocity and 5 a very high velocity). The distance from the river bank, and water depth were measured with a ranging pole and a tape measure, respectively.

Mussel dimensions (shell length, height, and width) were measured to the nearest $0.1 \mathrm{~mm}$ with a Vernier caliper. All specimens were carefully returned to the river in their original position after the collection of this information. To infer the population structure and confirm the

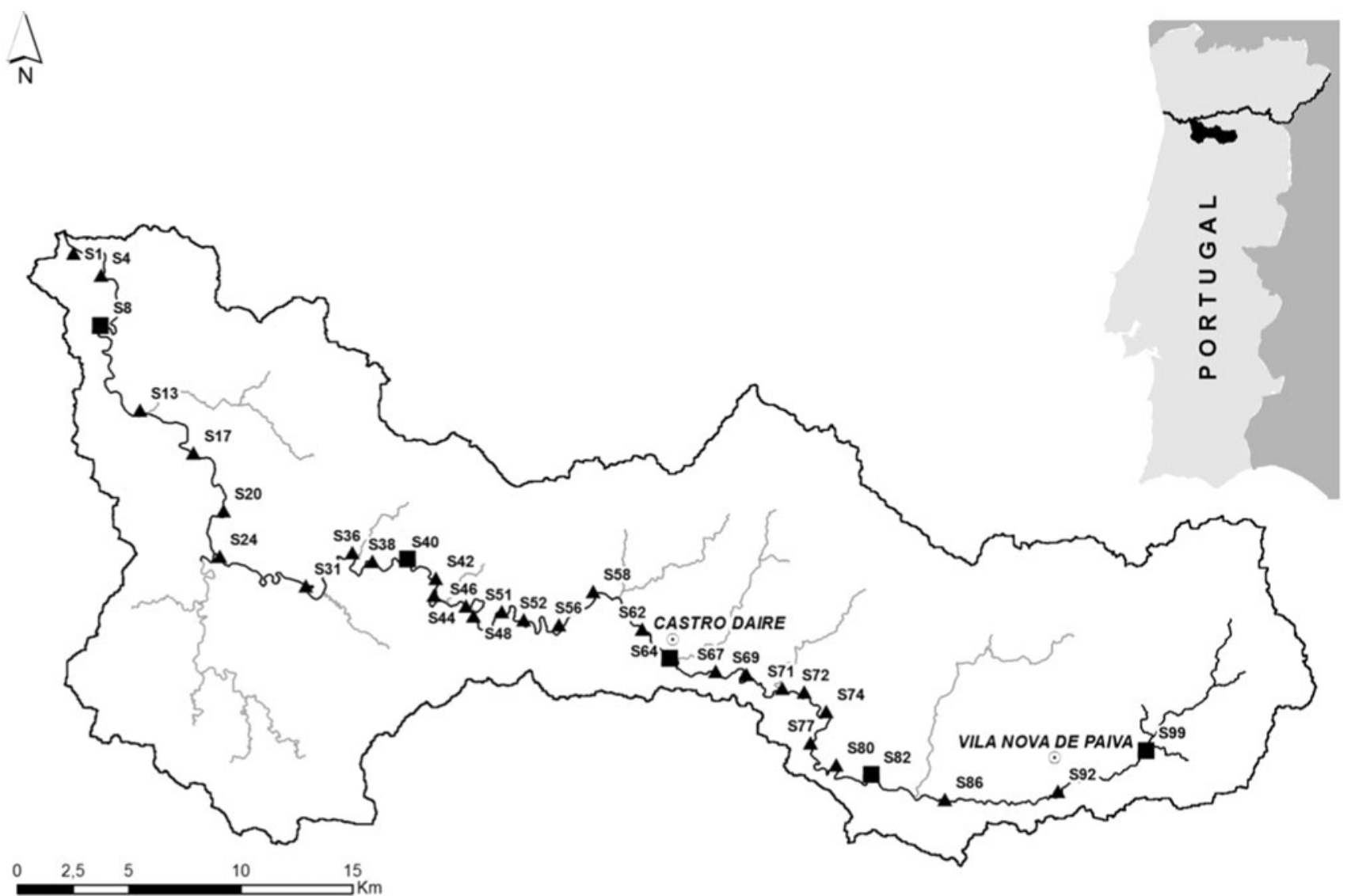

Fig. 1 Map of the River Paiva showing the 32 sites location (sites marked with a quadrate were also sampled for abiotic and fish fauna characterization) 
evidence of recent recruitment, a size-frequency distribution using $10 \mathrm{~mm}$ intervals was used following Young and others (2001). M. margaritifera juveniles were considered using the biologically based definition (up to $60 \mathrm{~mm}$ ) described by San Miguel and others (2004) for Iberian populations. According to these authors Iberian M. margaritifera populations reach maturity much earlier than northern populations, at around 6 years, which implies that specimens larger than $60 \mathrm{~mm}$ in length can be considered adults. Possible differences in mean lengths along sites were tested by Kruskal-Wallis since data depart from normality.

Fish fauna was assessed in the same five sites as the environmental characterization using electrofishing (backpack equipment with a pulsed DC-600 V generator). The voltage was set between 150 and $200 \mathrm{~V}$ in order to produce a current from 1.5 to $3 \mathrm{~A}$. Stunned fish were placed in containers to recover, identified to species level, counted, and released. The total area surveyed and total numbers of fish captured were recorded and fish densities were expressed as fish per $100 \mathrm{~m}^{2}$.

\section{Results}

\section{Environmental Characterization}

Environmental characterization in the five sites along the entire gradient of the River Paiva is presented in Table 1. Overall, there were some differences in the five sites mainly related to temperature that decreased from the mouth $\left(23.5^{\circ} \mathrm{C}\right.$ in S8) to the head $\left(19.1^{\circ} \mathrm{C}\right.$ in S99) of the river; nitrates had a much higher value at $\mathrm{S} 64$; and calcium and hardness had much lower values at S82. A total of 61 macroinvertebrate families were collected from the River Paiva. Aquatic insects belonging to pollution-sensitive orders of Ephemeroptera (mayflies), Plecoptera (stoneflies), and Trichoptera (caddisflies) dominated and the number of EPT families were high (22 families). As a result, WES, assessed using the benthic index of biotic integrity $\left(\operatorname{IPtI}_{\mathrm{N}}\right)$, was considered excellent at S8, S40, and S82 and good in S64 and S99 (Table 1). The evaluation of habitat quality showed that sites in the River Paiva have spatial differences in the RHS scores. Site 8 reached excellent quality and the remaining four sites were classified as good. The PCA (Fig. 2), using the abiotic data plus the results of the WES and RHS, revealed a clear spatial pattern. From this projection, sites appear distributed along an environmental gradient, with downstream sites along one of the edges (sites S8, S40 and S64) and upstream sites (sites S82 and S99) located at the other edge. The main factors responsible for the separation along the first axis were hardness and temperature and along the second axis WES and nitrates.

\section{Margaritifera margaritifera Ecological Status}

Margaritifera margaritifera was present in 19 of the 32 sites surveyed (Fig. 3). The most downstream site with individuals was located at S8 and the most upstream at S82 (further upstream no individuals were found although several sites were surveyed). We found a total of 353 individuals being the highest abundance ( 78 bivalves per $100 \mathrm{~m}$ of river stretch) recorded at S71. Several sites have more than 30 individuals per $100 \mathrm{~m}$ of the river stretch (S42, S67, S69, and S71) but the majority of sites had low numbers (Fig. 3).

The population structure showed a great dominance of large (and old) specimens (Fig. 4) with a maximum percentage of individuals in the size class of $80-90 \mathrm{~mm}$ and more than $80 \%$ of the individuals collected were larger than $70 \mathrm{~mm}$. Only $3.7 \%$ of specimens sampled in the River Paiva could be considered juveniles (lengths lower than $60 \mathrm{~mm}$ ). The mean mussel size found in the River Paiva was $83.0 \mathrm{~mm}( \pm 12.9 \mathrm{~mm} \mathrm{SD})$. The smallest individual collected was $25.2 \mathrm{~mm}$ and the largest was $110.1 \mathrm{~mm}$. There was a clear difference in the mean length of individuals at the different sites $(\mathrm{H}=128.6 ; P<0.001$; Fig. 5), with the individuals at downstream sites clearly larger than individuals from upstream sites.

More than $70 \%$ of the bivalves were collected within $4 \mathrm{~m}$ from the banks, with very few found in the middle of the river channel (Fig. 6). This species also preferentially colonized areas with velocities between categories 1 and 3 (Fig. 6). In relation to depth, the specimens were preferentially found at water depths between 50 and $100 \mathrm{~cm}$ and the preferential substrate for $M$. margaritifera was mainly comprised of sand and gravel in areas typically covered by riparian vegetation (Fig. 6).

Fish fauna was comprised of eight different species with one being non-native (Gobio lozanoi). Fish densities were very low and dominated by the presence of Pseudochondrostoma duriense (comprising $53.8 \%$ of all fishes captured). S. trutta was the unique host of M. margaritifera in this river and was present at all of the five survey sites but always at very low numbers (Table 2).

\section{Discussion}

Almost $80 \mathrm{~km}$ of the River Paiva contain M. margaritifera individuals and potentially have environmental conditions to support a healthy population (although we were not able to find live specimens between S52 and S67). The absence of specimens upstream of S82 and downstream of S8 may be explained by the lack of suitable habitat conditions for the species and due to lentic conditions caused by a dam in the River Douro which influences the first $4 \mathrm{~km}$ of the 
Table 1 Environmental characterization along the five sites sampled in the River Paiva

Overall results about the Water Ecological Status (WES) based on macroinvertebrates and the River Habitat Survey (RHS) are also included

\begin{tabular}{llllll}
\hline & S8 & S40 & S64 & S82 & S99 \\
\hline Temperature $\left({ }^{\circ} \mathrm{C}\right)$ & 23.50 & 22.57 & 21.43 & 20.30 & 19.10 \\
Dissolved oxygen $\left(\mathrm{mg} \mathrm{L}^{-1}\right)$ & 7.82 & 8.02 & 7.80 & 7.74 & 7.39 \\
$\mathrm{pH}$ & 6.45 & 6.59 & 6.10 & 6.00 & 6.42 \\
Conductivity $\left(\mu \mathrm{S} \mathrm{cm}^{-1}\right)$ & 56.50 & 49.90 & 54.50 & 37.50 & 41.10 \\
Nitrites $\left(\mathrm{mg} \mathrm{L}^{-1}\right)$ & $<0.03$ & $<0.03$ & $<0.03$ & $<0.03$ & $<0.03$ \\
Nitrates $\left(\mathrm{mg} \mathrm{L}^{-1}\right)$ & 3.11 & 4.13 & 7.05 & 2.35 & 3.01 \\
Phosphates $\left(\mathrm{mg} \mathrm{L}^{-1}\right)$ & $<0.31$ & $<0.31$ & $<0.31$ & $<0.31$ & $<0.31$ \\
Calcium $\left(\mathrm{mg} \mathrm{L}^{-1}\right)$ & 1.32 & 1.32 & 1.20 & 0.86 & 1.20 \\
Hardness $\left(\mathrm{mg} \mathrm{L}^{-1}\right)$ & 8.60 & 7.36 & 6.21 & 4.78 & 5.22 \\
Total suspended solids $\left(\mathrm{mg} \mathrm{L}^{-1}\right)$ & 8.00 & 10.00 & 8.00 & 10.00 & 7.00 \\
WES $\left(\mathrm{IPtI}_{\mathrm{N}}\right.$ index) & Excellent & Excellent & Good & Excellent & Good \\
RHS & Excellent & Good & Good & Good & Good \\
\hline
\end{tabular}

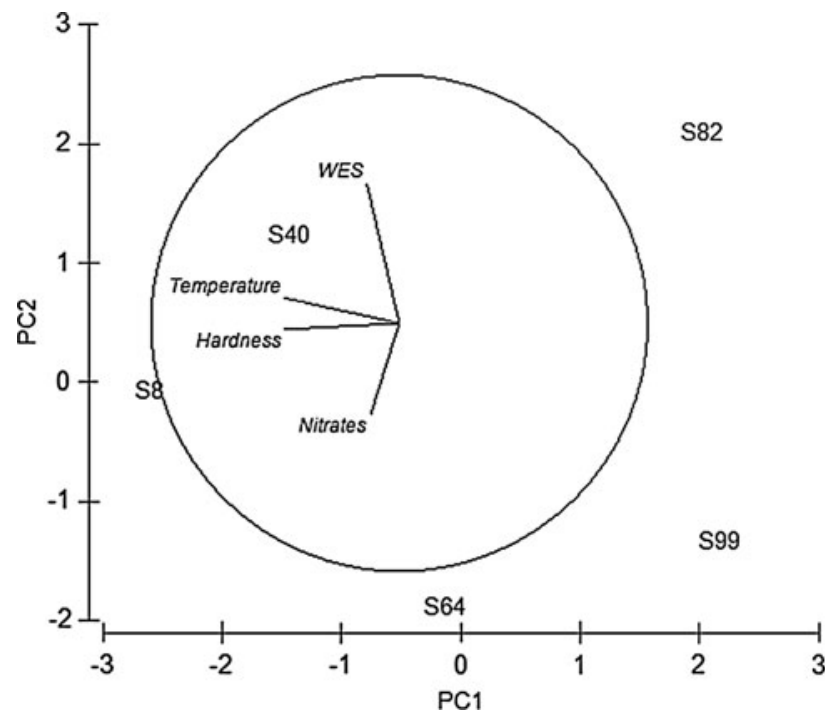

Fig. 2 Principal component analysis (PCA) showing the plotting of the five sites plus the two more informative factors per each axis. The percentage of variability explained by $\mathrm{PC} 1$ was $44.3 \%$ and PC2 $28.2 \%$
River Paiva, respectively. On the other hand the absence of specimens from S52 to S67 could be explained by the release of domestic effluents from the village of Castro Daire (site S64). This situation is clearly affecting the water quality since high nitrate levels and a lower WES was measured at site S64 in comparison with the other four sites.

This survey was very intensive and covered 32 different sites. The majority of sites had restricted access which prevented us doing a more complete environmental and fish fauna characterization due to logistic constrains. The abundances reported in this study should be regarded as minimum values due to the possibility of under-estimation of smaller mussels and of buried individuals, which would be hidden and escape our visual assessment. Even so, the total number of $M$. margaritifera may be more than 5,000 individuals along the entire river length. This estimation is based on the extrapolation of mussel abundance at individual sites to the length of the river with suitable habitat. This estimation is much higher than the one made by Reis (2003), which advance with a total population number of
Fig. 3 Number of $M$. margaritifera individuals per $100 \mathrm{~m}$ of river stretch along the 32 sites sampled in the River Paiva

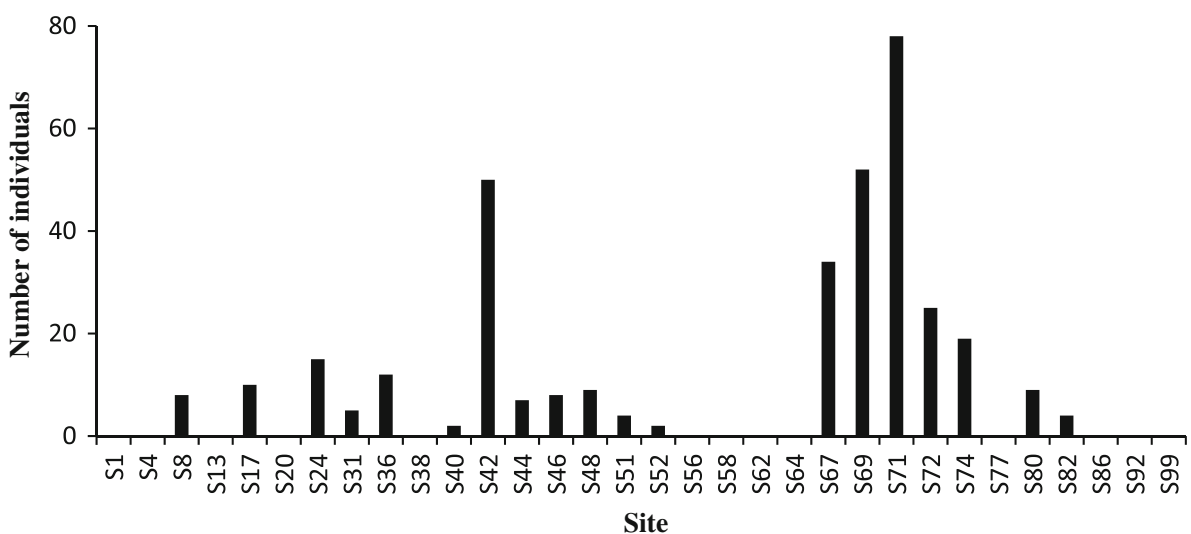




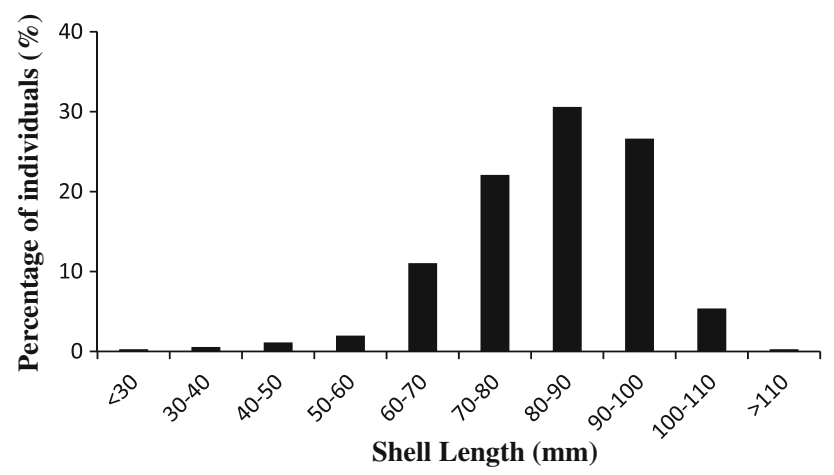

Fig. 4 Population structure of Margaritifera margaritifera in the River Paiva $(N=353)$

fewer than 500 individuals. This difference cannot be explained by a recovery in abundance in such a short period of time between sampling campaigns but by the much higher sampling effort of the present study.

The pearl mussel population structure in the River Paiva reveals acute aging with a great preponderance of individuals measuring over $70 \mathrm{~mm}$ in length (more than $80 \%$ of the individuals collected). This situation was already described in many Iberian and other European populations and is the major factor concerning the survival of this species (Álvarez-Claudio and others 2000; Hastie and others 2000b; Morales and others 2004; Outeiro and others 2008; Geist 2010; Österling and others 2010). However, the present study reveals that $3.7 \%$ of specimens sampled can be considered juveniles (lengths lower than $60 \mathrm{~mm}$ ). Therefore, River Paiva supports a functional pearl mussel population (i.e., at least one juvenile found, regardless of the overall numbers of adults present; Cosgrove and others 2000) mainly in upstream areas (discussed below). In addition, three individuals with a shell length lower than $32 \mathrm{~mm}$ were

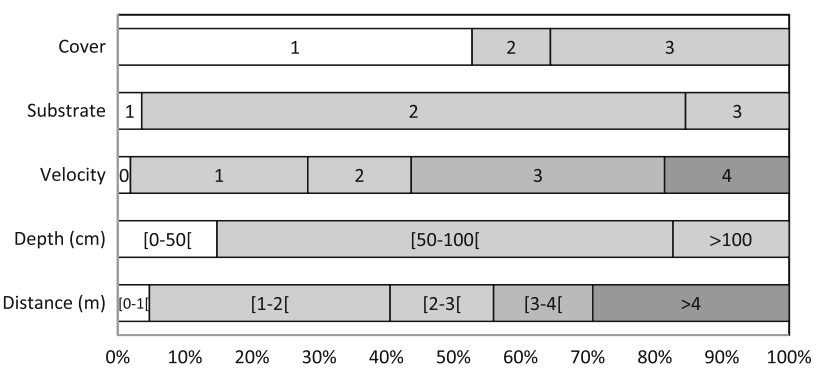

Fig. 6 Percentage of $M$. margaritifera individuals in relation to habitat characteristics: cover (qualitative data being 1 roots or vegetation; 2 cobbles or boulders; and 3 bedrock), dominant substrate (qualitative data being 1 roots; 2 sand and gravel; and 3 cobles, boulders, or bedrock), current velocity (qualitative data varying from 0 to 5 where 0 represent a null velocity and 5 a very high velocity); depth $(\mathrm{cm})$; and distance to banks $(\mathrm{m})$

Table 2 Density (ind. $100 \mathrm{~m}^{-2}$ ) of fish species along the five sites sampled in the River Paiva

\begin{tabular}{llllll}
\hline Species & S8 & S40 & S64 & S82 & S99 \\
\hline Achondrostoma oligolepis & - & 0.06 & 0.33 & 0.57 & 0.53 \\
Anguilla anguilla & 0.32 & - & - & - & - \\
Gobio lozanoi & 0.72 & - & - & - & - \\
Luciobarbus bocagei & 0.80 & 0.56 & - & - & - \\
Pseudochondrostoma duriense & 2.52 & 8.72 & 3.50 & 1.29 & - \\
Salmo trutta & 0.12 & 0.11 & 0.17 & 2.29 & 0.93 \\
Squalius alburnoides & 1.16 & 1.78 & - & - & - \\
Squalius carolitertii & 0.48 & 0.72 & - & 1.71 & 0.40 \\
\hline
\end{tabular}

found which means that recent recruitment has occurred in this river. Again, we must keep in mind that our survey was mainly focused in visible animals and so this may considerable under-estimate the presence of small individuals.
Fig. 5 Length of $M$. margaritifera in the River Paiva. Boxplots show median values (central line), the range from the first to the third quartile (box), Turkey whiskers and outliers (dots)

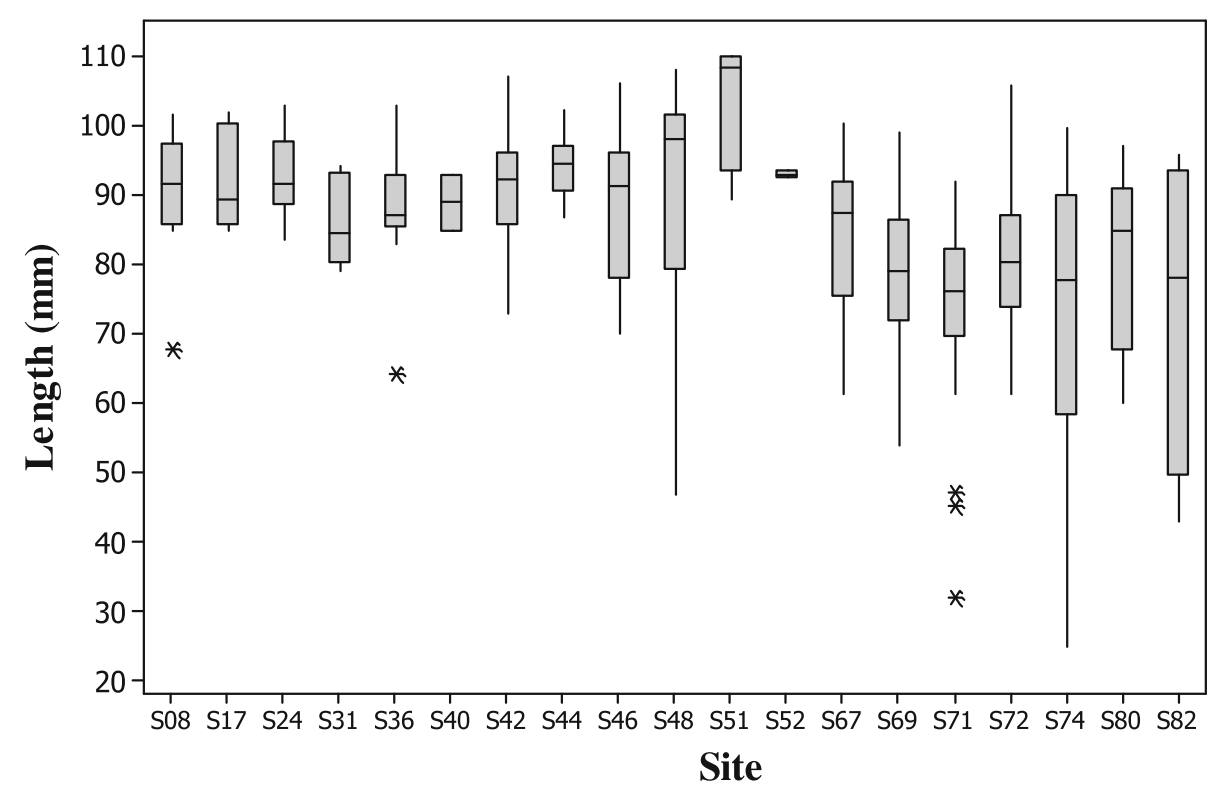


In the River Paiva, M. margaritifera showed a clear preference for areas near the banks at low depths, sandier and gravel sediments, a high degree of riparian vegetation cover, and in a wide range of current velocities. These preferences have been widely described for other European populations and follow very similar patterns (ÁlvarezClaudio and others 2000; Hastie and others 2000b; Morales and others 2004; Outeiro and others 2008). The high abundance in these areas can also be related with the preference of hosts (young trout) (Outeiro and others 2008).

Although the abiotic characterization was restricted to five sites and only covering the summer conditions (and so our conclusions should be considered with some caution), the area downstream S64 seems to present less suitable conditions for $M$. margaritifera mainly due to higher nitrate concentrations. This situation is the more probable explanation for the absence of specimens from S64 to S52 since it is well established that nutrient enrichment may impair the survival of $M$. margaritifera, particularly juveniles (Geist 2010). Since juveniles have specific habitat requirements: cool, well-oxygenated soft water free of pollution or turbidity, the release of domestic effluents may lead to nutrient enrichment and may impair recruitment and mussel survival (Varandas and others 2013). Interestingly, small/young mussels were only found in the area upstream of S64 which corroborates our findings that upstream sites have better environmental quality and are more suitable for mussel recruitment and survival. If our assumptions about nutrient enrichment and low flow conditions in summer adversely affecting $M$. margaritifera are correct, careful management of this situation should be a priority not only for the conservation of $M$. margaritifera but also to guarantee excellent water quality in this river. Thus, if this situation is reversed it is possible that this species could return to the $15-\mathrm{km}$ stretch of the river since suitable physical habitat exists.

The density of S. trutta (and also the other seven fish species) was very low along the five sites surveyed and this may be explained by the very low productivity of this river (however, this river has also low conductivity values which in some way can affect the electrofishing efficiency). According to some studies this lower trout density may be problematic for pearl mussels because it may result in lower total glochidia infections and so in a lower or even failure in recruitment (Arvidsson and others 2012). Although some authors suggest a density of at least five juvenile trout per $100 \mathrm{~m}^{2}$ to sustain a healthy M. margaritifera population (Bauer 1988; Ziuganov and others 1994), Geist and others (2006) support that similar densities as reported in the River Paiva may be sufficient to sustain a functional population. According to Geist and others (2006), low densities of host fish can be compensated by the higher glochidia carrying capacity of older host fish with limited previous contact with pearl mussel glochidia, by the long reproductive period of mussels, and by low mortality rates of juvenile mussels during their post-parasitic phase. Although it is impossible to establish a minimum threshold for the required density of host fish, the overall density of trout in the River Paiva seems to be low and this situation should be taken in account in future studies and in the application of conservation measures.

In addition to $M$. margaritifera, we also found three more species of freshwater bivalves in the River Paiva: Anodonta anatina, Corbicula fluminea, and Unio delphinus. The two native species A. anatina and $U$. delphinus were found in the first $13 \mathrm{~km}$ near the mouth of the river and the invasive $C$. fluminea was found from the mouth to S51. The presence of $C$. fluminea is particularly interesting since this river has very clear waters with oligotrophic conditions and has very high flows in the winter. Even so, this invasive species was able to colonize almost half of the length of this river; although the majority of individuals presented a very poor physiological condition (i.e., individuals with low biomass, shells very eroded and very few individuals had lengths larger than $25 \mathrm{~mm}$ ). While the abundance of $C$. fluminea in this river was not very high compared to other invaded systems special attention should be given to this species considering the already described ecological and economic impacts (for a review see Sousa and others 2008a, b). Indeed, if environmental conditions changed (increase in productivity due to higher nutrient release from domestic effluents or agricultural areas) it is possible that $C$. fluminea could increase its density and biomass and potentially intensify its ecological impact. In the same vein, the possible interaction between this invasive species and $M$. margaritifera should be taken in account in future studies.

In conclusion, the present work contributes to our knowledge of the current ecological status of $M$. margaritifera at the edge of its southern distribution. This information is important not only in terms of the present conservation status of the species but also as a reference for future alterations, including climate change. Possible alterations due to climate change can be particularly interesting to follow since the River Paiva is near the southern edge of the M. margaritifera distribution (in Portugal this river functions as the southern limit of distribution and just two populations in Spain are located further south-Rivers Agueda and Alberche; Velasco and others 2006). In the context of the Iberian Peninsula, the River Paiva can be considered an important habitat for pearl mussels and this population deserves conservational attention and effective protection. Given that the major environmental threats were identified (e.g., nutrient enrichment in medium and downstream areas due to the discharge of domestic effluents, presence of weirs, loss of 
riparian vegetation, and low density of trout) the main conservation requirements of $M$. margaritifera in River Paiva include maintaining or even improving the water quality (and if possible stopping the discharge of domestic effluents mainly near Castro Daire), increasing riparian vegetation cover, decommissioning several weirs to increase connectivity, and increasing the density of suitable hosts.

Acknowledgments We fully appreciated help given by Cátia Santos, Florbela Torres, Joaquim de Jesus, Marisa Lopes, Ricardo Azevedo, Sérgio Pereira, and Vitor Pereira during field surveys and to Louise Lavictoire for a careful revision. Suggestions made by three anonymous referees were also highly appreciated. Financial support was provided by Portuguese Foundation for Science and Technology (FCT) and COMPETE funds-projects "ECO-IAS" (Contract: PTDC/AAC-AMB/116685/2010) and CONBI (Contract: PTDC/ AAC-AMB/117688/2010).

\section{References}

Abell R, Allan JD, Lehner B (2007) Unlocking the potential of protected areas for freshwaters. Biol Conserv 134:48-63

Álvarez-Claudio C, Garcia-Rovés P, Ocharan R, Cabal JA, Ocharan FJ, Álvarez MA (2000) A new record of the freshwater pearl mussel Margaritifera margaritifera L. (Bivalvia, Unionoida) from the River Narcea (Asturias, north-western Spain). Aquat Conserv Mar Freshw Ecosyst 10:93-102

Arvidsson BL, Karlsson J, Österling ME (2012) Recruitment of the threatened mussel Margaritifera margaritifera in relation to mussel population size, mussel density and host density. Aquat Conserv Mar Freshw Ecosyst 22:526-532

Bauer G (1988) Threats to the freshwater pearl mussel, Margaritifera margaritifera in central Europe. Biol Conserv 45:239-253

Bauer G (1992) Variation in the life span and size of the freshwater pearl mussel. J Anim Ecol 61:425-436

Beasley CR, Roberts D (1996) The current distribution and status of the freshwater pearl mussel Margaritifera margaritifera L. 1758 in north-west Ireland. Aquat Conserv Mar Freshw Ecosyst 6:169-177

Carpenter SR, Stanley EH, Vander Zanden MJ (2011) State of the world's freshwater ecosystems: physical, chemical, and biological changes. Annu Rev Environ Resour 36:75-99

Cosgrove PJ, Young MR, Hastie LC, Gaywood M, Boon PJ (2000) The status of the freshwater pearl mussel Margaritifera margaritifera Linn. in Scotland. Aquat Conserv Mar Freshw Ecosyst 10:197-208

Darwall WRT, Holland RA, Smith KG, Allen D et al (2011) Implications of bias in conservation research and investment for freshwater species. Conserv Lett 4:474-482

Dudgeon D, Arthington AH, Gessner MO, Kawabata Z, Knowler DJ, Lévêque C, Naiman RJ, Prieur-Richard A, Soto D, Stiassny MLJ, Sullivan CA (2006) Freshwater biodiversity: importance, threats, status and conservation challenges. Biol Rev 81:163-182

Geist J (2010) Strategies for the conservation of endangered freshwater pearl mussels (Margaritifera margaritifera L.): a synthesis of conservation genetics and ecology. Hydrobiologia 644:69-88

Geist J, Porkka M, Kuehn R (2006) The status of host fish populations and fish species richness in European freshwater pearl mussel
(Margaritifera margaritifera L.) streams. Aquat Conserv Mar Freshw Ecosyst 16:251-266

Hastie LC, Young MR, Boon PJ, Cosgrove PJ, Henninger B (2000a) Sizes, densities and age structures of Scottish Margaritifera margaritifera (L.) populations. Aquat Conserv Mar Freshw Ecosyst 10:229-247

Hastie LC, Boon PJ, Young MR (2000b) Physical microhabitat requirements of freshwater pearl mussels, Margaritifera margaritifera (L.). Hydrobiologia 429:59-71

Hastie LC, Cosgrove PJ, Noranne E, Gaywood MJ (2003) The threat of climate change to freshwater pearl mussel populations. Ambio 32:40-46

INAG (2009) Critérios para a Classificação do Estado das Massas de Água Superficiais-Rios e Albufeiras. Ministério do Ambiente, do Ordenamento do Território e do Desenvolvimento Regional. Instituto da Água (in Portuguese)

Lydeard C, Cowie RH, Ponder WF, Bogan AE, Bouchet P, Clark SA, Cummings KS, Frest TJ, Gargominy O, Herbert DG, Hershler R, Perez KE, Roth B, Seddon M, Strong EE, Thompson FG (2004) The global decline of non-marine mollusks. BioScience 54:321-330

Morales JJ, Negro AI, Lizana M, MartÍnez A, Palacios J (2004) Preliminary study of the endangered populations of pearl mussel Margaritifera margaitifera (L.) in the River Tera (north-west Spain): habitat analysis and management considerations. Aquat Conserv Mar Freshw Ecosyst 14:587-596

Österling ME, Greenberg LA, Arvidsson BL (2008) Relationship of biotic and abiotic factors to recruitment patterns in Margaritifera margaritifera. Biol Conserv 141:1365-1370

Österling ME, Arvidsson BL, Greenberg LA (2010) Habitat degradation and the decline of the threatened mussel Margaritifera margaritifera: influence of turbidity and sedimentation on the mussel and its host. J Appl Ecol 47:759-768

Ostrovsky NA, Popov IYU (2011) Rediscovery of the largest population of the freshwater pearl mussel (Margaritifera margaritifera) in the Leningrad oblast (north-west Russia). Aquat Conserv Mar Freshw Ecosyst 21:113-121

Outeiro A, Ondina P, Fernandez C, Amaro R, Miguel ES (2008) Population density and age structure of the freshwater pearl mussel, Margaritifera margaritifera, in two Iberian rivers. Freshw Biol 53:485-496

Raven PJ, Holmes NTH, Dawson FH, Everard M (1998) Quality assessment using River Habitat Survey data. Aquat Conserv Mar Freshw Ecosyst 8:477-499

Régnier C, Fontaine B, Bouchet P (2009) Not knowing, not recording, not listing: numerous unnoticed mollusk extinctions. Conserv Biol 23:1214-1221

Reid N, Preston JS, Moorkens E, Roberts D, Wilson CD (in press) Conservation status and reproduction of the critically endangered freshwater pearl mussel (Margaritifera margaritifera) in Northern Ireland. Aquat Conserv Mar Freshw Ecosyst. doi: $10.1002 / \mathrm{aqc} .2306$

Reis J (2003) The freshwater pearl mussel [Margaritifera margaritifera (L.)] (Unionoida: Bivalvia) rediscovered in Portugal and threats to its survival. Biol Conserv 114:447-452

Ricciardi A, Rasmussen JB (1999) Extinction rates of North American freshwater fauna. Conserv Biol 13:1220-1222

San Miguel E, Monserrat S, Fernández C, Amaro R, Hermida M, Ondina O, Altaba CR (2004) Growth models and longevity of freshwater pearl mussels (Margaritifera margaritífera) in Spain. Can J Zool 82:1370-1379

Sousa R, Antunes C, Guilhermino L (2008a) Ecology of the invasive Asian clam Corbicula fluminea (Müller, 1774) in aquatic ecosystems: an overview. Ann Limnol 44:85-94

Sousa R, Nogueira AJA, Gaspar M, Antunes C, Guilhermino L (2008b) Growth and extremely high production of the nonindigenous invasive species Corbicula fluminea (Müller, 1774): 
possible implications for ecosystem functioning. Estuar Coast Shelf Sci 80:289-295

Strayer DL, Downing JA, Haag WR, King TL, Layzer JB, Newton TJ, Nichols SJ (2004) Changing perspectives on pearly mussels, North America's most imperiled animals. BioScience 54:429-439

Varandas S, Lopes-Lima M, Teixeira A, Hinzmann M, Reis J, Cortes R, Machado J, Sousa R (2013) Ecology of Southern European pearl mussels (Margaritifera margaritifera): first record of two new populations on the rivers Terva and Beça (Portugal). Aquat Conserv Mar Freshw Ecosyst 23:374-389

Velasco JC, Araujo R, Balset J, Toledo C, Machordom A (2006) First citation of Margaritifera margaritifera (L.) (Bivalvia, Unionoida) at the Tajo basin (Spain). Iberus 24:69-79
Vörösmarty CJ, McIntyre PB, Gessner MO, Dudgeon D, Prusevich A, Green P, Glidden S, Bunn SE, Sullivan CA, Liemann CR, Davies PM (2010) Global threats to human water security and river biodiversity. Nature 467:555-561

Young MR, Cosgrove PJ, Hastie LC (2001) The extend of, and causes for, the decline of a highly threatened Naiad: Margaritifera margaritifera. In: Bauer G, Waechtler K (eds) Ecology and evolution of the freshwater mussels Unionoida. Springer, Berlin, pp 337-357

Ziuganov V, Zotin A, Nezlin L, Tretiakov V (1994) The freshwater pearl mussel and the relationships with salmonid fish. VNIRO, Russian Federal Institute of Fisheries and Oceanography, Moscow 